\title{
Latvijas Republikas privāttiesību tiesu praksē laiks pāršķirt lappusi analoǵijas jēdziena un satura izpratnes attīstībā
}

\author{
Mg. iur. Rolands Kikors \\ Dukascopy Bank SA (Šveice) un AS Dukascopy Europe IBS, Latvija \\ rolands.kikors@gmail.com
}

\section{Kopsavilkums}

Rakstā tiek analizēta līdzšinējā Latvijas Republikas tiesu prakse, tostarp judikatūra, analogijas kā juridiskās metodes piemērošanā privāttiesībās. Pareiza analoǵijas piemērošana vairs nevar tikt saistīta tikai ar analoǵijas jēdziena iegaumēšanu un lietošanu noteiktās situācijās. Svarīgi ir ievērot arī no tiesību viedokḷa nozīmīgos materiāli tiesiskos aspektus, kā arī vērtēt pamattiesību trīskāršo ietekmi katrā konkrētā gadījumā. Apskatot šeit minētos apstākḷus privāttiesību kontekstā, var secināt, ka tiesām ir pienākums izvērtēt, vai labums, ko gūst prāvā uzvarējusī puse, objektīvi ir tāds un ne lielāks, kā tas būtu nepieciešams demokrātiskā sabiedrībā, un vai zaudējušai pusei piespriestais nav lielāks par nodarīto kaitējumu.

Atslēgvārdi: analogija, pamattiesību trīskāršā ietekme, privāttiesības.

\section{levads}

Atkal un atkal pārškirirot Latvijas privāttiesību tiesu prakses materiālus par analogijas piemērošanu un skatot tos par laiku kopš Latvijas Republikas neatkarības atjaunošanas, ar bažām jāvērtē tas, ko tiesas nospriedušas visās tiesu instancēs. Lai gan lietas dalībniekiem privāttiesisku jautājumu risināšanā ir visai lielas iespējas ietekmēt tiesas nolēmumu - šādas tiesības izriet no procesuālajiem normatīvajiem aktiem un Latvijas Republikas Satversmes (turpmāk - Satversme), bieži vien šis aspekts netiek ṇemts vērā un vispārējās jurisdikcijas tiesas analogija tiek piemērota vai nepiemērota patvalịgi, turklāt neievērojot analogijas jēdziena un satura izpētes robežas. Tādēl šajā publikācijā uzmanība pievērsta analog̣ijas piemērošanai tieši privāttiesībās, kurās pusēm netiek piešḳirtas tik lielas tiesiskās aizsardzības iespējas kā administratīvajās tiesībās un krimināltiesībās. 
Rolands Kikors. Latvijas Republikas privāttiesību tiesu praksē laiks pāršḳirt lappusi analogijas jēdziena un satura izpratnes attīstībā

Analog̣ijas piemērošana tiesu praksē juridiskā nozīmē ir visai "bīstama" juridiskā metode, jo kādas personas liktenis tiek izšḳirts nevis tā, kā to likumdevējs expresis verbis ir noteicis, bet gan līdzīgi, proti, mazliet citādi. Pirmšḳietami (prima facie) tas izskatās pretēji Satversmes 91. pantā noteiktajam: "Visi cilvēki Latvijā ir vienlīdzīgi likuma un tiesas priekšā. Cilvēka tiesības tiek īstenotas bez jebkādas diskriminācijas." [4]

Tomēr analogijas piemērošanas gadījumā pastāv gan piesaiste, gan saskaṇa ar likumu, kas tiek pamatota ar tiesību normas mērḳi un jēgumu. Turklāt analogijas slēdziena izejas punkts vienmēr ir jēdziens "līdzība" [48, 98]. Analog̣ija ir arī viena no tām retajām juridiskajām metodēm, uz kuras piemērošanu var paḷauties likumdevējs, ja tas no sevis neatkarīgu iemeslu dẹḷ nav spējis izdot tiesību normas visiem iespējamiem dzīves gadijumiem.

Analogijas kā jēdziena un satura izpratne juridiskajā literatūrā - vismaz Latvijā un Vācijā - ir visai plaši aprakstīta un analizēta. To darījuši vairāki Latvijā pazīstami tiesību zinātnieki, piemēram, E. Meḷkisis [46], J. Neimanis [47, 48], A. Plotnieks [49], E. Kalniṇš [41], G. Slaṇķe [52], kā arī starpkaru Latvijas tiesību zinātnieks V. Sinaiskis [51]. Savukārt Vācijā šim tematam pievērsis uzmanību ievērojamais tiesību zinātnieks J. Esers [39], T. Hellers [40], A. Kaufmans [42], D. Šmalzs [50], F. Budlinskis [37] u. c. Tādējādi interesentiem Latvijā pieejamas ne tikai savas valsts tiesību zinātnieku atziņas, bet arī vācu tiesību zinātnieku pētījumi - pietiekams informācijas apjoms par analogijas jēedzienu un saturu. Vai tas ir arī pilnvērtīgs mācību materiāls, kas ḷauj izprast analog̣ijas jēdziena un satura pareizu piemērošanu reālajā dzìvē? Ar to diemžèl nepietiek, jo modernā sabiedrībā nepieciešams studēt un analizēt arī analogiijas piemērošanas praksi kopsakarā ar mūsdienu modernajām vajadzībām.

Kāpēc uzmanība tiek pievērsta tieši analogijai, nevis kādai citai juridiskai metodei? Tāpēc, ka tiesu praksē analogiija ir visvairāk piemērotā juridiskā metode [49, 313]. Tajā pašā laikā analoǵija ir arī visvairāk kḷūdaini piemērotā juridiskā metode, kas ieskicē diezgan pamatīgas problēmas fizisko un juridisko personu tiesiskajā aizsardzībā tur, kur pusēm per se šāda aizsardzība ir ievērojami mazāka nekā administratīvajās lietās un krimināllietās. Šāds secinājums ir gūts, iepazīstoties ar Latvijas tiesu praksi privāttiesībās, kas izveidojusies pēc neatkarības atjaunošanas. Problēmas ir gan analoǵijas jēdziena un satura nepareizā piemērošanā, gan analogiijas piemērošanā tur, kur nav šādas vajadzības, gan nepiemērošanā tur, kur tas ir vitāli svarīgi. Savukārt bieži vien kḷūdainā analog̣ijas piemērošana un / vai nepiemērošana ir klišejiski iesakṇojoties tiesu praksē, piemēram, privāttiesībās, turklāt tā skar arī cilvēka pamattiesību trīskāršo ietekmi un vairs neatbilst Satversmē garantētajām cilvēka pamattiesībām. Lai gan strīds ir starp divām privātpersonām, cilvēka pamattiesību aizskārums var izpausties arī nepareizi piemērotas vai nepiemērotas analoǵijas un līdz ar to arī kḷūdaina sprieduma veidā.

Raksta mērḳis ir veicināt analog̣ijas jēdziena un satura izpratni ne tikai juridiskajā literatūrā un tiesu praksē, bet arī plašāk, tādējādi stiprinot kā fizisko, tā juridisko personu tiesisko aizsardzību tieši privāttiesībās. Rakstā tiek pierādīts, ka privāttiesisku strīdu daba jau per se izgaismo analogijas piemērošanas problēmas. 
Rolands Kikors. Latvijas Republikas privāttiesību tiesu praksē laiks pāršḳirt lappusi analogijas jēdziena un satura izpratnes attīstībā

\section{Privāttiesību tiesu prakses / judikatūras statistiskā analīze}

Analogijas jēdziena un satura problemātika izriet no Latvijas Republikas privāttiesību tiesu prakses. Turklāt ne tikai no pirmās instances tiesu vai apgabaltiesu prakses, bet arī no Latvijas Republikas Augstākās tiesas (turpmāk - Augstākā tiesa) prakses, tostarp judikatūras. Savukārt, ja kḷūdas var saskatìt judikatūrā, jāpadomā, kāds izglìtības līmenis tiek piedāvāts tiesību zinātṇu studentiem, praktiḳiem un tiesību normu piemērotājiem. Iepazīstoties un analizējot kopumā 72, manuprāt, nozīmīgākos spriedumus kopš Latvijas Republikas neatkarības atjaunošanas, var konceptuāli secināt, ka statistiskie rāditāji ir šādi:

- divās trešdaḷās gadījumu analog̣ija tiek attiecināta uz materiālo tiesību normām;

- vienā trešdaḷā gadijjumu analogija tiek attiecināta uz procesuālo tiesību normām;

- nedaudz vairāk kā 50\% gadījumu tiek piemērota likuma analog̣ija;

- pārējos gadījumos tiek piemērota tiesību analogiija.

Tomēr jānorāda, ka laikposmā no 2016. gada līdz šim brīdim šie rādītāji ir samazinājušies.

Tiesas spriedumos aplūkotajos gadījumos analogijas jēdziena un satura izpratnes problēmas izpaudās šādi:

- tiesas neatškīira likuma analog̣iju no tiesību analogiijas;

- no atsevišķiem nolēmumiem vispār nebija saprotams, kā tiesas nonākušas pie analogiijas piemērošanas / nepiemērošanas secinājumiem;

- atsevišķos nolēmumos netika vērtēti no tiesību viedokḷa nozīmīgi materiāli tiesiskie aspekti, lai lietu varētu objektīvi izspriest;

- tiesas analogiju nepamatoti piemēroja gadijjumos, kuros tas nebija nepieciešams, un nepiemēroja tajos, kuros tas bija nepieciešams;

- tiesas, piemērojot analogiiju, neñēma vērā Satversmē nostiprinātās personu pamattiesības un vienlìdzỉbas un taisnīguma principu.

Analog̣ijas jēdziena un satura izpratnes un piemērošanas problemātika tiesu praksē ir diezgan satraucoša, tādẹl raksta turpinājumā sniegts izklāsts par analogiijas jēdziena un satura pareizu izpratni un piemērošanu kopsakarā ar tiesas piel̦autajām kḷūdām.

\section{Likuma un tiesību analoǵijas nepareiza piemērošana}

Jau no jēdzieniem "likuma analog̣ija" un "tiesību analog̣ija" iespējams vispārīgi secināt, ka likuma analogiija attiecas uz kādu konkrētu likuma normu (ar likuma normu šeit tiek saprasti ārējie normatīvie akti), bet tiesību analog̣ija - uz daudzām tiesībām (tiesības šeit ir jāsaprot plašākā nozīmē), kuras jāpiemēro pēc analoǵijas. Viens no Latvijas tiesību zinātniekiem A. Plotnieks norāda, ka likuma analog̣ija (latīnu val. analogia legis) ir tiesību normas attiecināšana uz gadỉjumu, uz kuru norma pēc tās vārdiskā formulējuma jēgas tieši neattiecas, bet kurš pēc būtiskajām pazīmēm ir līdzīgs normas hipotēzē 
Rolands Kikors. Latvijas Republikas privāttiesību tiesu praksē laiks pāršḳirt lappusi analogijas jēdziena un satura izpratnes attīstībā

aprakstītajam gadījumam [49, 327]. Piemērojot likuma analogiiju, tiek meklēts kopsaucējs starp tiesisko sastāvu un faktisko sastāvu [37, 477]. Papildus tam jānorāda, ka likuma analogija ir individuāla analogiija, kuru piemērojot tiek izmantota noteikta tiesību norma. Pirmkārt, noskaidro tiesību normu, kuras hipotēze visvairāk atbilst faktiskajiem apstākliiem; otrkārt, noskaidro, vai nepastāv slēdziens par pretējo (latīnu val. argumentum a contrario); treškārt, pārbauda, cik stipra ir analoğija un vai tā ir sociāli nepieciešama tās efektivitātes ziṇā; ceturtkārt, veic subsumpciju [54, 96-97].

Turpretī, piemērojot tiesību analogiju (latīnu val. analogia iuris), no vairākiem normatīvajiem noteikumiem tiek izsecināts vispārējs tiesību princips, kurš pēc sava satura un jēgas ir attiecināms uz normatīvajā aktā neregulētu gadỉjumu, tāpat kā uz regulētajiem gadījumiem $[44,383]$. Tiesību analogiijas rezultāts ir vispārējs tiesību princips, par kuru runā kā tiesību tālāku veidošanu, kas izgājusi ārpus iespējamās vārdiskās jēgas, ja tiesneša nolēmums nerada tikai vienu noteikumu vienam konkrētam sastāvam, bet tā radītais noteikums attiecas uz nenoteiktu gadỉjumu skaitu [48, 102]. Vācu tiesību zinātnieks F. Budlinskis norāda arī uz atšḳirību starp analogiijas ceḷā radītajiem vispārējiem tiesību principiem un vispārējiem ("dabiskajiem") tiesību principiem [37, 477]. Proti, ja, piemērojot analog̣iju, faktiskajam sastāvam pēc būtības tiek pielīdzināta tiesību norma ar pilnvērtīgu tiesisko sastāvu un tiesiskajām sekām, tad vispārējie ("dabiskie") tiesību principi satur tikai kādu vispārēju vērtību un uzdevumu, bet atklāts paliek jautājums, kā to precīzi realizēt vai kā atbilstoši piemērot no tā izrietošãs tiesiskās sekas. Tiesu praksē bieži vien tiek runāts arī par tiesību normu analogiju, tomēr tiesas parasti ar to ir domājušas tieši tiesību analog̣iju [51]. Pastāv arī tiesu nolēmumi, no kuriem var izsecināt, ka tiesa, lietojot vārdus "tiesību normu analogija”, jauc likuma analogiju ar tiesỉbu analogiju, nenonākot pie konstruktīva un strikta viedokḷa, kurš analoǵijas veids tad issti jāpiemēro [18].

Tiesu praksē vērojami vairāki spriedumi, kuros tiesas neatšḳir likuma analoǵiju no tiesību analog̣ijas un gala secinājuma izdarī̌̌anai kā pamatojumu izvēlas vienu konkrētu veidu. Piemēram, Cēsu rajona tiesas 2017. gada 12. jūnija spriedums lietā Nr. C11059217 ir tipisks tiesību analog̣ijas piemērošanas gadỉjums, kurā tiesa to ir nosaukusi par likuma analogiiju [16]. Šādi spriedumi aplūkojamā jautājuma kontekstā nav retums, un tie pien̦emti (tas izriet no publiski pieejamās informācijas) vismaz kopš 2013. gada [12, 13, 14, 15, 16, 17, 26, 28, 29, 31]. Spriedumos tika analizēts jautājums, vai personai, kura sasniegusi 18 gadu vecumu un kura studē izglìtības iestādē, un kura pati nespēj sevi apgādāt, šĩ iemesla dēḷ ir tiesības no apgādātāja saṇemt uzturlīdzekḷus. Tiesas secinājumu pamatā tika izmantotas šādas tiesību normas: Civillikuma 179. pants: "Vecāku pienākums ir samērā ar viṇu spējām un mantas stāvokli uzturēt bērnu"; 219. pants: "Nepilngadība abu dzimumu personām turpinās tik ilgi, kamēr tās sasniedz astonpadsmit gadu vecumu" [1] un likuma "Par valsts pensijām" 19. panta ceturtā daḷa: "Par darba nespējīgiem ǵimenes locekḷiem uzskatāmas arī šã panta otrajā un trešajā daḷā norādītās personas, kuras nav sasniegušas 24 gadu vecumu, ja tās laikā, kad iestājusies apgādnieka nāve, vai vēlāk mācās vai studē vispārējās, profesionālās izglìtības iestādēs, koledžās vai augstskolās pilna laika klātienē, izn,emot laiku, kad persona ir pārtraukusi studijas" [7]. Tiesa konstatēja, ka persona, lai 
arī ir sasniegusi 18 gadu vecumu, nevar sevi apgādāt, turklāt šādu iespēju neizslēdz arī minētā likuma "Par valsts pensijām" 19. panta ceturtā daḷa. Tomēr tiesa sprieduma taisīšanas pamatā tieši atsaucās uz likuma analogiiju, lai gan no sprieduma ir acìmredzams, ka tiesa lietas iznākuma panākšanai kopsakarā izvērtēja gan Civillikuma 179. pantu un 219. pantu, gan likuma "Par valsts pensijām" 19. panta ceturto daḷu. Tādējādi tiesa ieguva vispārīgu secinājumu, ka ikviena no iepriekš minētajām tiesību normām satur ko tādu, kas tiek likts galīgā slēdziena taisīšanas pamatā. Tādēl šeit nevar runāt par likuma jeb individuālo analogiiju, bet tā ir tiesību analog̣ija. Papildus minētajam jānorāda, ka sabiedrībā varētu rasties jautājums, kāpēc publiskot šādu tiesas piel̦autu kḷūdu, ja neatkarīgi no tā, vai tiesa atsaucas uz likuma analoǵiju vai tiesību analoǵiju, sprieduma iznākums paliek nemainīgs? Atbilde ir pavisam vienkārša - vienotas tiesu prakses, doktrīnas un izpratnes par analogijias jēdziena un satura metodoloǵisko piemērošanu veidošanai ir nepieciešams veicināt sabiedrisko diskusiju par šādām problēmām, lai esošie un topošie tiesību zinātnieki un tiesību normu piemērotāji būtu motivēti izglìtoties un praktizēt tiesu sistēmā, kurā viṇi var paḷauties, ka juridiskā kvalitāte gan kopumā, gan analogiijas piemērošanā ir visaugstākajā līmenī.

\section{Nepietiekama analīze un vērtēšana}

Nepietiekama analogijas satura un jēdziena analīze daudzos gadījumos var būt ne tikai iemesls nepareiza sprieduma pien,emšanai, bet arī turpmākai gan tiesas, gan ārpustiesas strīdu risināšanai. Turklāt sprieduma objektivitātes trūkums var izpausties arī tajā, ka tiesas nevērtē no tiesību viedokḷa nozīmīgos materiāli tiesiskos aspektus, lai vispār nonāktu pie analog̣ijas piemērošanas. No tiesību viedokḷa nozīmīgi materiāli tiesiskie aspekti ir tie, kas vienoti un bez pretējas tagadnes izpratnes atzìti kā ārējos normatìvajos aktos, tā arī doktrīnā un judikatūrā. Tas nozīmē, ka tiesību normu piemērotājam pirms galīgās izšḳiršanās par analoǵijas piemērošanu jāapsver, vai argumentācija, ar kuru pamato tiesību normu piemērotāja secinājumus, nav pretrunā ar citām tiesību normām, vispārējiem tiesību principiem, doktrīnu un judikatūru. Vienlaikus tiesnesim jāapsver, kādas juridiskās sekas tiks radītas sprieduma adresātam un vai šīs sekas bez papildu argumentācijas nebūs acīmredzamā pretrunā ar pastāvošajiem uzskatiem.

Piemēram, Augstākā tiesa kādā spriedumā atzina, ka arī rakstiski nenoslēgtiem darba līguma grozījumiem pēc analogiijas ir piemērojams Darba likuma 41. pants, kurā ir akcentēta rakstiski nenoslēgta darba līguma atzīšana un ietērpšana rakstiski [22]. Šo Augstākās tiesas atziṇu savā argumentācijā izmantoja pirmās instances tiesa un apelācijas instances tiesa, ko var konstatēt no cita Augstākās tiesas sprieduma - 2015. gada 26. janvāra sprieduma lietā Nr. SKC-1650/2015 [23]. Tomēr pati Augstākā tiesa šo apstākli nevērtēja un atzina, ka šajā gadïjumā nav piemēroja ma analogiija. Problēmu radīja tas, ka minētie darba līguma grozijumi, kuri, pēc pirmās un apelācijas instances tiesas ieskata, de facto atbilst analogiijai ar Darba likuma 41. pantu, bija tādi, kas acīmredzami pasliktina darbinieka tiesisko stāvokli. Augstākā tiesa šo apstākli neṇēma vērā, tomēr tai bija 
pienākums izvērtēt, vai šis ir tas gadījums, kurā darba līguma grozỉjumus, kas acīmredzami pasliktina darbinieka tiesisko stāvokli, ir vērts apspriest saistībā ar analog̣ijas piemērošanu. Ja tas būtu vērtēts, Augstākā tiesa, iespējams, nonāktu pie secinājuma, kurš veicinātu daudzpusīgu diskusiju turpmākajos ārpustiesas un tiesas strīdos, jo šādi darba līguma grozījumi nav piemērojami pēc analogijas ar Darba likuma 41. pantu.

To var pamatot arī ar taisnīguma principu. Latviešu tiesību zinātnieks E. Meḷkisis norādīijis, ka taisnīguma princips ir pamatā dzīves gadījuma faktiskā sastāva līdzībai ar normas tiesisko sastāvu, proti, ka līdzīgi gadījumi ir izšḳirami līdzīgi [46, 60], pamatojoties uz Satversmes 91. pantu. Arī vācu tiesību zinātnieks R. Cipēliuss uzskata, ka, piemērojot analoǵiju, jāievēro taisnīguma princips [55, 62], pretējā gadījumā tas būtu netaisnīgi visos analoğiskajos gadỉjumos, piemēram, minētā Augstākās tiesas sprieduma kontekstā - rakstiski nenoslēgti darba līguma grozijjumi tiktu atzîti un noslēgti rakstiski pēc analogijas ar Darba likuma 41. pantu.

Papildus jānorāda, ka arī Augstākās tiesas 2012. gada 25. janvāra spriedumā lietā Nr. SKC-18/2012 ir saskatāmas zināmas analogijas jēdziena un satura piemērošanas problēmas [22]. Šajā spriedumā Augstākā tiesa pēc analogijas piemēroja Civilprocesa likuma 406. pantu, kas tolaik sastāvēja no vairākām daḷām, un ne visas no tām attiecās uz konkrēto gadïjumu [2].

Izprotot likuma analogiiju, ne vienmēr jāaprobežojas tikai ar kādu konkrētu likuma pantu, dal̦u vai punktu, bet gan tieši ar to tiesisko sastāvu, kuru var pēc visām nepieciešamajām līdzībām pakārtot faktiskajiem apstākḷiem. Tādējādi, skrupulozi neizvērtējot, kuras vārdkopas attiecas uz konkrēto dzìves gadījumu un ir piemērojamas pēc analogijas, var, pirmkārt, nonākt pie nepareiza secinājuma; otrkārt, radīt problemātiku tiesību normu piemērotājiem piemērot to pašu normu pēc analogijas un atsaukties uz šīm tiesas atziṇām nākotnē.

Visbeidzot, kādā citā Augstākās tiesas spriedumā - 2003. gada 5. novembra spriedumā lietā Nr. SKC-534 - tiesa secināja: ja darbinieks uzreiz pēc prettiesiskas atlaišanas ir strādājis citā, mazāk apmaksātā amatā, tad pēc analogiijas ar Darba likuma 126. panta otro dalı darbiniekam ir tiesības tikai uz starpību starp jaunā darba samaksu un iepriekšèjā darba vidējo izpeḷnu [18]. Tomēr Augstākā tiesa neizvērtēja šādus no tiesību viedokḷa nozīmīgus materiāli tiesiskos aspektus: pirmkārt, vai darbinieks līdztekus iepriekšējai darbavietai ir strādājis citur (šis apstāklis būtu n,emams vērā, lai noteiktu kopējo tajā laikā saṇemto atalgojumu un aprēḳinātu izmaksājamo starpību); otrkārt, vai darba devējs var palikt nesodìts gadỉjumā, ja viņš ir patvaḷigi rīkojies un darbiniekam vidējās izpel̦nas starpība neveidojas (jo citu tiesiskās aizsardzības līdzekḷu, ja netiek pierādīta atšḳirīga attieksme vai diskriminācija, darbiniekam nav). Tādējādi Augstākās tiesas spiedums, vismaz daḷēji, nav pareizs un minētā Augstākās tiesas nostāja būtu jāpārskata, kā tas jau minēts nesenajā tiesību doktrīnā [43]. 
Rolands Kikors. Latvijas Republikas privāttiesību tiesu praksē laiks pāršḳirt lappusi analogiijas jēdziena un satura izpratnes attīstībā

\section{Analoǵijas nepamatota piemērošana un nepiemērošana}

Tiesu praksē bieži vien vērojama tendence bez īpašas analīzes piemērot analoǵiju tur, kur nav nepieciešams, bet nepiemērot tur, kur ir nepieciešams. Viens no šãdas rīcības iemesliem ir tiesas nepareizā izškirš̌anās, vai konkrētajā lietā ir piemērojama kāda no tiesību normu iztulkošanas metodēm vai arī jāizvēlas tiesību tālāka veidošana. Robeža starp abām minētajām tiesību normām vienmēr ir to vārdiskajā jēgā [53, 128]. Turklāt tiesas līdz galam neizvērtē taisnīguma principu un arī to, vai konkrētā tiesību normas piemērošanas konstrukcija vispār attiecas uz analogiju juridiskā nozīmē.

Piemēram, Bauskas rajona tiesa 2016. gada 1. novembra spriedumā lietā Nr. C10072815, konstatējot, ka prasītājs nav pilnīgi samaksājis valsts nodevu, piedzina šo nodevu par labu valstij no atbildētāja, pēc analogijas piemērojot Civilprocesa likuma 42. panta pirmo daḷu: "[..] ja prasītājs no to samaksāšanas bijis atbrīvots [..]." Tomēr šis tiesas secinājums ir kḷūdains, jo šajā situācijā tiek pārkāpts taisnīguma princips. Proti, likumā ir regulētas situācijas, kurās prasītājs no valsts nodevu samaksas ir atbrīvots, piemēram, trūcīgā statusa dẹl. Savukārt šajā gadījumā tiesa lēmuma par lietas ierosināšanu pieṇemšanas brīdī neatstāja prasības pieteikumu bez virzỉbas un šo savu kḷūdu piesprieda atbildētājam, kurš faktiski varēja paḷauties, ka prasītājs par civilprocesu norēḳināsies saskaṇā ar likumu. Tā vietā tiesa piesprieda šĩs naudas summas iekasēt no atbildētāja.

Jau iepriekš šajā rakstā tika norādīts, ka analoǵijas piemērošana pamatojas uz taisnīguma principu. Tādēḷ pirms analog̣ijas piemērošanas tiesai bija jāizvērtē, vai šāda izšḳiršanās ir taisnīga un atbilstoša. Savukārt kādā citā spriedumā Latgales apgabaltiesas Civillietu tiesas kolēgija noraidīja analoǵiju, kā vienīgo argumentu izmantojot šādu viedokli: "[..] analogiija šajā gadījumā nav piemērojama, jo minētā tiesību norma neregulē pušu tiesiskās attiecības." [17] Rezultātā kḷūdains ir arī spriedums. Ja tiesību norma regulētu pušu tiesiskās attiecības, tad analogiijas piemērošana nebūtu nepieciešama, pietiktu minēto normu iztulkot. Savukārt, ja minētā norma neregulē pušu tiesiskās attiecības, tad jāmeklē lïdzības starp tiesību normu un gadījumu no dzīves. Tad, iespējams, būtiskie apstākḷi sakristu un analogiija būtu piemērojama.

Visbeidzot, kādā no spriedumiem tiesa ir palaidusi garām atbildētāja ierosinājumu pēc analoğijas piemērot nepārvaramu varu, kura, kā to sacījis atbildētājs, nav definēta Civillikumā, tāpēc tā jāaizṇemas no UNIDROIT starptautiskajiem komerclīgumu principiem [8]. Tomēr jānorāda, ka saskaṇā ar analogiijas teoriju nepārvarama vara kā nenoteikts juridisks jēdziens nav piemērojama pēc analog̣ijas, un tiesību normu, kura satur nenoteiktu juridisku jēdzienu, nevar piemērot pēc analogiijas, ja par analoǵijas piemērošanas apstākli tiek izmantots tieši nenoteikts juridisks jēdziens. Analogiija ir tiesību tālākas veidošanas paṇēmiens atklāto likuma "robu" aizpildīšanai [41, 326]. Savukārt nepārvarama vara, kā to norādījis ievērojamais latviešu tiesību zinātnieks E. Levits, vispirms jāpiepilda ar konkrētu saturu konkrētā gadījuma kontekstā $[45,166]$. Ja minētais gadījums neatbilst nepārvaramas varas definīcijai, tad nav konstatējami nepārvaramas varas apstākḷi. 
Un tieši tāpēc, ka nenoteikts juridisks jēdziens pirms tā piemērošanas jāaizpilda ar saturu, konkrētajā gadỉjumā analog̣ija nav piemērojama, jo nepastāv atklāts likuma "robs".

Nenoteikti juridiski jēdzieni nav piemērojami pēc analogijias, līdzīgi jāizturas arī pret tiesību normām, kuras satur generālklauzulas (piemēram, labi tikumi, laba ticība). Tās nav piemērojamas pēc analog̣ijas, ja minētā generālklauzula tiek izmantota par analogiijas piemērošanas apstākli. Šāds secinājums ir cieši saistīts ar generālklauzulu jēdziena izpratni, proti, šie jēdzieni pirms to piemērošanas ir jāpiepilda ar konkrētu saturu visai kazuistiskā veidā, meklējot universālas un juridiski abstraktas vadlīnijas [45, 162-205]. Jānorāda gan, ka ne vienmēr tiesa, analoǵiju nepamatoti piemērojot vai nepiemērojot, lietu izspriež nepareizi. Tieši pretēji - sprieduma gala rezultāts dažkārt ir pareizs un taisnīgs, tāpēc apstrīdēt tā būtību uz analogiijas nepareiza jēdziena un satura izpratnes pamata nebūtu pareizi.

\section{Normatīvā regulējuma, kas transformēts salīdzināmā tiesību sistēmā, piemērošana pēc analoǵijas}

Diezgan maz ir apskatīts jautājums par tiesiskām attiecībām, kas citā salīdzināmā tiesību sistēmā radušās pirms sprieduma pien̦emšanas un uz kurām agrāk attiecās pavisam cits normatīvais regulējums. Pēc analogijas jāpiemēro jaunāks normatīvais regulējums, kas pien̦emts jaunā tiesību sistēmā. Viens no šādiem prakses gadījumiem ir strīds starp Latvijas Republikas Kultūras ministriju un AS "Rīgas Kinostudija" [24], kas sabiedrībā guva plašu rezonansi. Augstākā tiesa vērtēja, vai prasītājam - Latvijas Republikas Kultūras ministrijai - pieder īpašuma tiesības uz AS "Rīgas Kinostudija” uzṇemtajām filmām, kuras tika radìtas pirms Latvijas Republikas neatkarības atjaunošanas, t. i., Padomju Latvijas laikā. Kultūras ministrijai viens no argumentiem bija šāds: vēl pirms Latvijas Republikas neatkarības atjaunošanas filmas, par kurām ir strīds, pārgāja valsts īpašumā, tātad arī pēc neatkarības atjaunošanas tām jābūt valsts īpašumā. Pamatojumā tika norādīts Latvijas Republikas Augstākās Padomes 1993. gada 11. maija lēmuma "Par Latvijas Republikas likuma "Par autortiesībām un blakustiesībām" spēkā stāšanās kārtību" 8. punkta 2. apakšpunkts: "Uzdot Latvijas Republikas Ministru Padomei līdz 1993. gada 15. maijam iesniegt Latvijas Republikas Augstākajai Padomei likumprojektu par valsts īpašumā esošo audiovizuālu darbu tālākas izmantošanas kārtību, n,emot vērā šā likuma 11. pantā noteiktās autortiesības." [6]

Tomēr Augstākā tiesa secināja:

"Apsverot vēlākā normatīvā regulējuma attiecināšanu uz juridisko personu autortiesībām pēc analogiijas, proti, tā transformāciju salīdzināmā tiesību institūtā, kas atbilst Latvijas tiesību sistēmai, ṇemams vērā, ka likumdevējs Latvijas Republikas Augstākās Padomes 1993. gada 11. maija lēmumā "Par Latvijas Republikas likuma "Par autortiesībām un blakustiesībām” spēkā stāšanās kārtību” 8. punkta 2. apakšpunktā pauda noteiktu gribu jautājumā par, tā ieskatā, valstij piekritīgām filmām regulēt ar atsevišksu normatīvo aktu. Neraugoties 
Rolands Kikors. Latvijas Republikas privāttiesību tiesu praksē laiks pāršḳirt lappusi analogijas jēdziena un satura izpratnes attīstībā

uz lēmumā izmantoto neprecīzo izteiksmi [ar to, visticamāk, tiesa domāja to, ka lēmuma 8. punkta 2. apakšpunktā ir minēti valsts īpašumā esoši darbi - R. K.], secināms, ka likumdevējs jautājumu par strīdus periodā radītajām filmām bija vēlējies regulēt patstāvīgi. Atbilstošs normatīvais regulējums nav pienemts līdz pat šim brīdim. 2010. gadā pienemot Filmu likumu, likumdevējs noregulēja tikai jautājumu par valstij jau piederošu tiesību izmantošanu, taču attiecībā uz strīdus periodā tapušajām filmām nenoteica to veidošanā iesaistīto subjektu tiesību veida, apjoma, aizsardzības ilguma un piederības jautājumus. Šādos apstākḷos, kad likumdevējs ir paudis gribu tiesisko situāciju regulēt pats, analogija nav piemērojama, un juridisko personu autortiesības atzīstamas par pārstājušām pastāvēt vēlākais ar likuma "Par autortiesībām un blakustiesībām” spēkā stāšanās brīdi." [24]

Sprieduma pareizība nav apstrīdama, tomēr ir nepieciešams attīstīt šo Augstākās tiesas argumentāciju atbilstoši analogiijas jēdziena un satura izpratnei. Proti, ja reiz Augstākā tiesa secināja, ka minētais Latvijas Republikas Augstākās Padomes lēmums ir uzrakstīts neprecīzi un nav noregulējis juridisko personu autorību, tad log̣iski rodas jautājums, kā un vai ir nepieciešams noregulēt Latvijas Republikas kā sākotnējās juridiskās personas tiesības uz filmām. Atbilde meklējama tajā, ka pēc Latvijas Republikas neatkarības atjaunošanas tiesību sistēma tika transformēta un padomju laika tiesību akti vairs nav juridiski saistoši. Tādējādi izveidojas situācija, kurā juridiski nepastāv tiesiskās attiecỉbas, kurām pēc analog̣ijas varētu piemērot Latvijas Republikas Augstākās Padomes lēmumu, un tātad a priori nevar runāt par kādu tiesību tālāku veidošanu, jo tiesību tālākai veidošanai nav juridiskā pamata.

\section{Pamattiesību trejkāršā ietekme - būtisks priekšnoteikums analoǵijas jēdziena un satura metodoloǵiski pareizai piemērošanai}

Mūsdienās analog̣ijas piemērošanai vairs nav tikai teorētiska nozīme, kas pamatota ar pareizu jēdziena un satura izpratni. Metodoloǵiski pareizas piemērošanas pamatā ir arī Satversmē nostiprinātās pamattiesības, kuras jāievēro ne tikai administratīvajām tiesām un krimināltiesām, bet arī vispārējās jurisdikcijas tiesām, kurām, izskatot horizontālos strīdus, jāṇem vērā arī personu pamattiesības. To, ka konstitucionālās tiesības aizsargā arī analogiijas piemērošanu privāttiesībās, pamato Satversmes tiesas 2001. gada 5. decembra spriedumā lietā Nr. 2001-07-0103 minētais:

"Cilvēktiesību aizsardzība kā viena no tiesiskas valsts svarīgākajām garantijām nosaka valsts pienākumu nodrošināt efektīvu aizsardzību ikvienam, kura tiesības ir pārkāptas. [..] Konstitucionālās tiesības aizsargā gan privātpersonu intereses, gan ar īpašumu saistītās sabiedriskās attiecības, kā arī konstitucionālās tiesības piešḳir tiesības tiešajiem tiesisko attiecību dalībniekiem aizsargāt savas konstitucionālās tiesības. [..] Kā jebkura cilvēktiesību norma, arī Satversmes 92. panta trešajā teikumā ietvertā tiesību norma ir piemērojama tieši un nepastarpināti. Bez tam šì norma neparedz, ka tās konkretizēšanai nepieciešams īpašs likums. Šãda likuma neesamība ir saistāma ar Satversmes 92. panta trešā teikuma tiešas piemērošanas iespēju un nevar būt iemesls atteikumam pieṇemt tiesā indivīda prasību par atlīdzinājuma piedziṇu." [36] 
Lìdzīgu nostāju ir paudusi arī Augstākā tiesa savā 2009. gada 20. maija spriedumā lietā Nr. SKC-383/2009: "Darbinieku pret psihologiisko teroru aizsargā ne tikai Satversme, bet arī Darba likums." [20]

Log̣iski izriet, ka darbinieku pret otru privāttiesību subjektu - darba devēju - aizstāv arī Satversme. Arī Latvijas tiesību zinātnieks Dr. iur. Edvīns Danovskis norāda, ka cilvēka pamattiesību ietekme privāttiesiskajās attiecībās vairs netiek apšaubīta [38, 118-130]. Kā vienu no šeit analizētajiem spriedumiem pamattiesību trīskāršās ietekmes kontekstā jāmin Augstākās tiesas Civillietu departamenta 2006. gada 14. jūnija lēmumu lietā Nr. SKC-488 19], kurā Augstākā tiesa secināja: "Līdz ar to netiek sasniegts likuma mērkis garantēt procesa dalībniekiem tiesības pārsūdzēt tiesas lēmumu saskaṇā ar Civilprocesa likuma 449. panta trešo dalı un Satversmes 92. pantu."

Savukārt par kḷūdainu un no pamattiesību viedokḷa prettiesisku spriedumu ir uzskatāms jau šajā publikācijā pieminētais Augstākās tiesas 2003. gada 5. novembra spriedums lietā Nr. SKC-534 [18], kurā tiesa, neizvērtējot Satversmes 106. panta saturu, nevietā piemēroja analogiju, kura šajā gadijjumā pavisam noteikti nebija nepieciešama. Papildus jānorāda, ka analogiijas jēdziena un satura metodologiijas īpatnības privāttiesībās jāskata kopā ar Satversmē nostiprināto taisnīguma un vienlīdzības principu. Ja izveidojas situācija, kurā tiek atklāts likuma "robs", pirmkārt, detalizēti jāizvērtē, vai pastāv analogijas piemērošanas sākotnējie priekšnoteikumi kopsakarā ar izskatāmo dzīves gadījumu; otrkārt, jāṇem vērā arī Satversmē nostiprinātās garantijas likuma "roba" aizpildīšanā; treškārt, atsevišḳi jāizdara nepieciešamie apsvērumi par taisnīguma un vienlīdzības principa ievērošanu un piemērošanu. Ja kāda no trīs elementiem trūkst vai kāds netiek pilnībā izpildīts, pastāv iespēja, ka tiesa var izdarìt kḷūdainu secinājumu un šādā veidā a priori aizskart personas pamattiesības.

\section{Secinājumi un priekšlikumi}

1. Analizējot Latvijas tiesu praksi / judikatūru, kas izveidojusies kopš Latvijas Republikas neatkarības atjaunošanas, var secināt, ka analoğija ir visvairāk kḷūdaini piemērotā juridiskā metode. Šādas kḷūdas rada visai pamatīgas problēmas fizisko un juridisko personu tiesiskajā aizsardzībā gadỉjumos, kuros pusēm per se šāda aizsardzība ir ievērojami mazāka nekā administratīvajās lietās un krimināllietās.

2. Analog̣ijas jēdziena un satura izpratnes metodologijas problēmas ir saskatāmas gan analoğijas jēdziena un satura nepareizā piemērošanā, gan analoǵijas piemērošanā gadijjumos, kuros tas nav nepieciešams, un analog̣ijas nepiemērošanā tajās reizēs, kad piemērošana ir vitāli svarīga.

3. Bieži piel̦autā kḷūdainā analogiijas jēdziena un satura izpratne, klišejiski iesakṇojoties tiesu praksē, piemēram, privāttiesību kontekstā, skar arī cilvēka pamattiesību trīskāršo ietekmi un vairs neatbilst Satversmē garantētajām cilvēka pamattiesībām, kuras tiesām jāṇem vērā metodologiski pareiza nolēmuma sagatavošanā. 
Rolands Kikors. Latvijas Republikas privāttiesību tiesu praksē laiks pāršḳirt lappusi

analogiijas jēdziena un satura izpratnes attīstībā

4. Ja izveidojas situācija, kurā atklāts likuma "robs", pirmkārt, detalizēti jāizvērtē, vai pastāv analog̣ijas piemērošanas sākotnējie priekšnoteikumi kopsakarā ar izskatāmo dzīves gadījumu; otrkārt, jāṇem vērā arī Satversmē nostiprinātās garantijas likuma "roba" aizpildīšanā; treškārt, atseviškłi jāizdara nepieciešamie apsvērumi par taisnīguma un vienlīdzības principa ievērošanu un piemērošanu.

\title{
It is Time to Turn Over a New Page in Evolution of Understanding the Concept and Matter of Analogy in Private Law Court Practice in the Republic of Latvia
}

\begin{abstract}
In the article, past practice and judicature of the courts of the Republic of Latvia on the implementation of analogy method have been studied. Correct implementation of analogy method cannot include mere memorisation and implementation of it in particular situations. It is also important to consider substantial material law aspects and evaluate the presence of the triple influence of human rights in each private legal relationship separately. By reviewing previously mentioned aspects in the scope of private law, courts have a duty to evaluate whether in democratic society one of the parties is satisfied as much as possible, but the other party must not suffer more than it did any damage to the first.
\end{abstract}

Keywords: analogy, triple influence of human rights, private law.

\section{Avoti un literatūra}

\section{Tiesību akti}

1. Civillikums: Latvijas Republikas likums. Valdības Vēstnesis. 41, 20.02.1937. Iegūts no: https:// likumi.lv/doc.php?id=225418 [sk. 13.04.2018.].

2. Civilprocesa likums: Latvijas Republikas likums. Latvijas Vēstnesis. 326/330(1387/1391), 03.11.1998. Iegūts no: https://likumi.lv/doc.php?id=50500 [sk. 13.04.2018.].

3. Darba likums: Latvijas Republikas likums. Latvijas Vēstnesis. 105(2492), 06.07.2001. Iegūts no: https://likumi.lv/doc.php?id=26019 [sk. 13.04.2018.].

4. Latvijas Republikas Satversme: Latvijas valsts likums: pieñemts 15.02.1922. Latvijas Vēstnesis. 43, 01.07.1993. Iegūts no: https://likumi.lv/doc.php?id=57980 [sk. 13.04.2018.].

5. Par autortiesībām un blakustiesībām: Latvijas Republikas likums: zaudējis spēku. Latvijas Vēstnesis. 31, 29.05.1993. Iegūts no: https://m.likumi.lv/doc.php?id=56878 [sk. 13.04.2018.].

6. Par Latvijas Republikas likuma "Par autortiesībām un blakustiesībām" spēkā stāšanās kārtību": LR Augstākās Padomes lēmums: stājās spēkā 11.05.1993., zaudējis spēku. Latvijas Vēstnesis. 31, 29.05.1993. Iegūts no: https://likumi.lv/doc.php?id=56879 [sk. 13.04.2018.]. 
Rolands Kikors. Latvijas Republikas privāttiesību tiesu praksē laiks pāršḳirt lappusi

analogijas jēdziena un satura izpratnes attīstībā

7. Par valsts pensijām: Latvijas Republikas likums. Latvijas Vēstnesis. 182(465), 23.11.1995. Iegūts no: https://likumi.lv/doc.php?id=38048 [sk. 13.04.2018.].

8. UNIDROIT starptautiskie komerclīgumu principi. Iegūts no: https://www.unidroit.org/english/ principles/contracts/principles2010/blackletter2010-english.pdf [sk. 13.04.2018.].

\section{Tiesu prakse}

9. Balvu rajona tiesas 2013. gada 20. decembra spriedums lietā Nr. C09031913.

10. Cēsu rajona tiesas 2015. gada 26. marta spriedums lietā Nr. C11061715.

11. Cēsu rajona tiesas 2015. gada 31. augusta spriedums lietā Nr. C11090715.

12. Cēsu rajona tiesas 2016. gada 19. oktobra spriedums lietā Nr. C11092216.

13. Cēsu rajona tiesas 2017. gada 10. marta spriedums lietā Nr. C11044617.

14. Cēsu rajona tiesas 2017. gada 27. marta spriedums lietā Nr. C11045217.

15. Cēsu rajona tiesas 2017. gada 9. maija spriedums lietā Nr. C11052817.

16. Cēsu rajona tiesas 2017. gada 12. jūnija spriedums lietā Nr. C11059217.

17. Latgales apgabaltiesas Civillietu tiesas kolēgijas 2014. gada 15. maija spriedums lietā Nr. C09020413.

18. Latvijas Republikas Augstākās tiesas Civillietu departamenta 2003. gada 5. novembra spriedums lietā Nr. SKC-534. Nav publicēts.

19. Latvijas Republikas Augstākās tiesas Civillietu departamenta 2006. gada 14. jūnija lēmums lietā Nr. SKC-488.

20. Latvijas Republikas Augstākās tiesas Civillietu departamenta 2009. gada 20. maija spriedums lietā Nr. SKC-383/2009. Nav publicēts.

21. Latvijas Republikas Augstākās tiesas Civillietu departamenta 2010. gada 10. novembra spriedums lietā Nr. SKC-821. Nav publicēts.

22. Latvijas Republikas Augstākās tiesas Civillietu departamenta 2012. gada 25. janvāra spriedums lietā Nr. SKC-18/2012.

23. Latvijas Republikas Augstākās tiesas Civillietu departamenta 2015. gada 26. janvāra spriedums lietā Nr. SKC-1650/2015.

24. Latvijas Republikas Augstākās tiesas Civillietu departamenta 2017. gada 31. janvāra spriedums lietā Nr. SKC-69/2017.

25. Rēzeknes rajona tiesas 2016. gada 25. augusta spriedums lietā Nr. C26151816.

26. Rēzeknes rajona tiesas 2016. gada 31. oktobra spriedums lietā Nr. C26208916.

27. Rēzeknes tiesas 2014. gada 8. aprīla spriedums lietā Nr. C26045214

28. Rēzeknes tiesas 2014. gada 8. aprīḷa spriedums lietā Nr. C26045314.

29. Rēzeknes tiesas 2015. gada 29. aprīla spriedums lietā Nr. C26120514.

30. Rēzeknes tiesas 2015. gada 19. maija spriedums lietā Nr. C26120014.

31. Rēzeknes tiesas 2015. gada 30. septembra spriedums lietā Nr. C26105115.

32. Rēzeknes tiesas 2015. gada 11. novembra spriedums lietā Nr. C26129915.

33. Rēzeknes tiesas 2016. gada 16. februāra spriedums lietā Nr. C26130215.

34. Rēzeknes tiesas 2016. gada 25. februāra spriedums lietā Nr. C26130115.

35. Rīgas pilsētas Kurzemes rajona tiesas 2014. gada 2. jūnija spriedums lietā Nr. C28280413.

36. Satversmes tiesas 2001. gada 5. decembra spriedums lietā Nr. 2001-07-0103. Iegūts no: http:// www.satv.tiesa.gov.lv/cases/?case-filter-years=\%5B2001\%5D\&case-filter-status=\&case-filtertypes $=\&$ case-filter-result $=\&$ searchtext [sk. 04.04.2018.]. 
Rolands Kikors. Latvijas Republikas privāttiesību tiesu praksē laiks pāršḳirt lappusi analogijas jēdziena un satura izpratnes attīstībā

\section{Literatūra}

37. Bydlinski, F. 1991. Juristische Methodenlehre und Rechtsbegriff. 2., erg. Aufl. Wien.

38. Danovskis, E. Horizontal Effect of Basic Human Rights in Private Law as a Common Trend of European Integration. No: European Integration and Baltic Sea Region: Diversity and Perspectives. 2011. Riga: University of Latvia Press.

39. Esser, J. 1972. Vorverständnis und Methodenwahl in der Rechtsfindung: Rationalitätsgarantien der richterlicher Entscheidungspraxis. Frankfurt am Main: Athenäum.

40. Heller, T. 1961. Logik und Axiologie der analogen Rechtsanwendung. Berlin: de Gruyter.

41. Kalniņš, E. 2005. Privāttiesību teorija un prakse. Rìga: Tiesu namu aǵentūra.

42. Kaufmann, A. 1982. Analogie und Natur der Sache. 2. verbess. und ergänzte Aufl. Heidelberg: R. V. Decker \& C. F. Müller.

43. Kikors, R. 2017. Darbinieka likumā noteikto tiesību uz atlīdzību pēc prettiesiska uzteikuma pilnveidošana. Jurista Vārds. 45(999), 31.10.2017.

44. Larenz, K. 1991. Methodenlehre der Rechtswissenschaft. 6. Aufl. Berlin.

45. Levits, E. 2003. G̦enerālklauzulas un iestādes rīcības brīvība. Likums un Tiesības. 5. sēj., 6(46).

46. Mel̦ịisis, E. 2000. Attīstības tendences dažos tiesību teorijas un prakses jautājumos. Rīga: Latvijas Universitāte.

47. Neimanis, J. 2004. Ievads tiesībās. Rīga: zvērināts advokāts Jānis Neimanis.

48. Neimanis, J. 2006. Tiesību tālākveidošana. Rīga: Latvijas Vēstnesis.

49. Plotnieks, A. 2013. Tiesību teorija E juridiskā metode. Rīga: Izglītības solii.

50. Schmalz, D. 1992. Methodenlehre für das Juristische Studium. 3. Aufl. Baden-Baden: Nomos Verlagsgesellschaft.

51. Sinayskiy, V. 2000. Tekhnika yuridicheskoy metodologii v svyazi s obshchim ucheniyem o metodologii. Riga: RGSO. (Синайский, В. Техника юридической методологии в связи с общим учением о методологии. Рига: РГСО, 2000).

52. Slaṇḳe, G. 2012. Tiesību tālākveidošana krimināltiesībās. Jurista Vārds. 37(736), 11.09.2012.

53. Tiesību tālākveidošana. No: Juridiskās metodes pamati. 11 soḷi tiesību normu piemērošanā. 2003. E. Meḷkisis, zin. red. Rīga: Latvijas Universitāte.

54. Weinreb, L. (2005). Legal Reason: the Use of Analogy in Legal Argument. Cambridge University Press.

55. Zippelius, R. 1994. Juristische Methodenlehre. 6. Aufl. Munchen: C. H. Beck'sche Verlagsbuchhandlung. 